\title{
Study Report on Retrospective Clinical Follow-up of Post Exposure Prophylaxis with Inj. Anti Rabies Vaccine (ARV) or Inj. Anti Rabies Vaccine (ARV) + Inj. Rabies Immunoglobulin (RIG) in Animal Bite Patients Attending at BITID
}

\author{
Dr. Hasina Nasreen, MD ${ }^{1 *}$, \\ Dr. Mamunur Rashid, MD ${ }^{2}$ \\ Dr. Enshad Ekramullah, FCPS ${ }^{3}$ \\ Dr. Rumana Rashid, $\mathrm{MPH}^{4}$ \\ ${ }^{* 1,2,3}$ Tropical Medicine, Bangladesh Institute of Tropical and Infectious Diseases (BITID), \\ Chittagong, Bangladesh \\ ${ }^{4}$ Epidemiology and Community Medicine, Bangladesh Institute of Tropical and Infectious Diseases (BITID), \\ Chittagong, Bangladesh \\ (hasinanasreen2018@gmail.com) \\ This journal is licensed under a Creative Commons Attribution-Noncommercial 4.0 International License (CC-BY-NC). \\ Articles can be read and shared for noncommercial purposes under the following conditions: \\ - BY: Attribution must be given to the original source (Attribution) \\ - NC: Works may not be used for commercial purposes (Noncommercial) \\ This license lets others remix, tweak, and build upon your work non-commercially, and although their new works must \\ also acknowledge you and be non-commercial, they don't have to license their derivative works on the same terms. \\ License Deed Link: http://creativecommons.org/licenses/by-nc/4.0/ \\ Legal Code Link: http://creativecommons.org/licenses/by-nc/4.0/legalcode \\ $A B C$ Research Alert uses the CC BY-NC to protect the author's work from misuse.
}

\section{Abstract}

Rabies is a universally fatal and equally preventable zoonotic disease that is prevalent in Bangladesh. Bangladesh Institute of Tropical \& Infectious Diseases (BITID) is the national institute for tropical-infectious diseases in the country which is working as a center for rabies control under the Rabies Elimination Program of the Centers for Disease Control and Prevention (CDC). This report is about the cumulative follow-up of patients inflicted with animal bites who had attended the institute during the period of September 2014 to December 2015. The characteristics of animal bites and subsequent clinical outcome of the post-exposure prophylaxis with ARV and/or RIG in the prevention of Rabies was recorded. About 1398 patients were analyzed in two groups, Group A comprised of 886 patients receiving Inj ARV only and Group B included 512 patients who received both of Inj ARV and RIG. Among the analyzed patients, Category 11 bites were more prevalent at $54.7 \%$. The total of $84 \%$ of the patients who attended for rabies PEP completed the vaccination schedule. Most of the CAT- III patients attended the institute within 2 days of the animal bites. No patients had any adverse effect following vaccination or RIG and none had developed Rabies

Keywords

Animal-bites; Rabies; BITID; ARV; RIG. 


\section{INTRODUCTION}

Rabies, a neglected tropical zoonotic disease claims more than 2,000 lives annually in Bangladesh. It is $100 \%$ fatal and also $100 \%$ preventable if appropriate preventive measures are taken in due time. ${ }^{[1]}$ Annual number of dog-bites in Bangladesh varies between 200,000 and 300,000 and $95 \%$ of rabies occur due to rabid dog bites. ${ }^{[2]}$ In Bangladesh other rabid animals are cat, foxes, monkey, jackal, mongoose etc. In BITID from September 2014 to December 2015 about 1700 animal bite patients came for rabies prophylaxis. With the national rabies elimination goal by 2020 in mind, a number of activities are being conducted by the rabies elimination program, such as national rabies survey, setting up of national and district rabies prevention and control centers, mass dog vaccination and management of dog population. Intra-dermal tissue culture-based rabies vaccines are now being used replacing the locally-produced nerve tissue vaccines for dog-bites. After being bitten by an animal, patients are assessed for the categorization of the bites according to WHO guidelines. In CAT I bite only washing of the affected area has been recommended. ARV only in CAT II \& ARV and RIG in CAT III are recommended by the guidelines. ${ }^{[3]}$ Human diploid cell vaccine is licensed for intramuscular use. The vaccine may cause mild transient local reactions (e.g.-pain at the injection site, redness, swelling and indurations) among 60 to 89.5 percent of vaccines. Purified chick embryo cell vaccine also shows similar side effects but cause less frequent local reactions than human diploid cell vaccines which have been noted at a frequency of 4 per 100 vaccines. ${ }^{[4]}$ Modern cell culture vaccines $(\mathrm{CCV})$ are more effective and safer, but expensive. Rabies immunoglobulin is of two types like HRIG (Human rabies immunoglobulin) and ERIG (Equine rabies immunoglobulin). HRIG usually produces no adverse effect but ERIG may produce some side effects like hyper-sensitivity reaction. In this study cell culture vaccine (either purified chick embryo cell vaccine or human diploid cell vaccine) had been given to group A patients and both cell culture vaccine and ERIG had been given to group B patients and subsequently their effects had been followed up.

\section{MATERIALS AND METHODS}

Data from all the patients who attended the BITID for post-exposure prophylaxis following animal bite had been recorded in the rabies vaccination register provided by the Rabies Elimination Program. Patient confidentiality had been strictly maintained. For the preparation of the study report on retrospective clinical follow up of post exposure prophylaxis with ARV or ARV +RIG among animal bite patients attending the BITID during the period of September, 2014 to December, 2015, all the available patient information from rabies vaccination register had been compiled with a data table.

A total of 1708 persons received vaccination during the mentioned period. The data of 1398 patients had been analyzed and the rest 310 patients were excluded from the analysis because of the incompleteness of the information in the register book or any other reasons. The 1398 patients were analyzed in two groups, Group A comprised of 886 patients receiving Inj ARV only and the Group B included 512 patients who received both of Inj ARV and RIG.

Though there was no clear guidelines from the elimination program regarding when and how the patients should be followed up after the vaccination, every patient was asked individually to report to the center for anything abnormal they notice following the prophylaxis. No patient was found to have reported with any complications of either ARV or RIG, as well as no rabies cases were reported among patients who received prophylaxis from the center. Subsequently the patients had been contacted individually 2 to 6 months following the 
vaccination over their mobile phones for the confirmation of the fact.

After completion of collection, the obtained data was checked, verified, edited and coded. All the data was recorded in a computerized structured form. After registering the personal information examination findings and investigation findings of the patients each form was saved as a distinct file in a definite folder of a specific computer. After achieving the target number of patient within the study time the obtained data were analyzed and statistical evaluation was performed by SPSS 20 program.

\section{RESULTS AND DISCUSSION}

\section{Results}

\begin{tabular}{|l|l|l|l|}
\hline $\begin{array}{c}\text { Base line demo- } \\
\text { graphy }\end{array}$ & $\begin{array}{c}\text { Group A } \\
(\text { ARV) } \\
(\mathbf{n = ~ 8 8 6})\end{array}$ & $\begin{array}{c}\text { Group B } \\
(\text { ARV+RIG) } \\
(\mathbf{n = ~ 5 1 2 )}\end{array}$ & $\begin{array}{c}\text { Total } \\
(\mathbf{n = 1 3 9 8})\end{array}$ \\
\hline $\begin{array}{l}\text { Age Group : } \\
\text { < 15 Years }\end{array}$ & $433(48.9 \%)$ & $299(58.4 \%)$ & $732(52.4 \%)$ \\
$\geq 15$ Years & $453(51.1 \%)$ & $213(41.6 \%)$ & $666(47.6 \%)$ \\
\hline $\begin{array}{l}\text { Sex : } \\
\text { Male }\end{array}$ & $509(57.4 \%)$ & $370(72.3 \%)$ & $879(62.9 \%)$ \\
Female & $377(42.6 \%)$ & $142(27.7 \%)$ & $519(37.1 \%)$ \\
\hline
\end{tabular}

Table - 1: Baseline data among the study groups $(\mathrm{n}=1398)$

Table 1 shows among the study subjects, about $52 \%$ were under 15 years of age and about $49 \%$ were at or above 15 years. Male were predominantly affected in both study groups $(57.4 \%$ vs $72.3 \%)$.

\begin{tabular}{|c|c|c|c|}
\hline $\begin{array}{c}\text { Animal Bite Related } \\
\text { Data }\end{array}$ & $\begin{array}{c}\text { Group A } \\
(\text { ARV) } \\
(\mathbf{n}=\mathbf{8 8 6})\end{array}$ & $\begin{array}{c}\text { Group B } \\
(\text { ARV+RIG) } \\
(\mathbf{n}=\mathbf{5 1 2})\end{array}$ & $\begin{array}{c}\text { Total } \\
(\mathbf{n}=\mathbf{1 3 9 8})\end{array}$ \\
\hline $\begin{array}{l}\text { Site of Bite : } \\
\text { Lower Limb } \\
\text { Upper Limb } \\
\text { Head/Face } \\
\text { Trunk } \\
\text { Multiple Bites }\end{array}$ & $\begin{array}{l}600(67.7 \%) \\
199(22.5 \%) \\
35(4.0 \%) \\
34(3.8 \%) \\
18(2 \%)\end{array}$ & $\begin{array}{l}261(51.0 \%) \\
106(20.7 \%) \\
88(17.2 \%) \\
32(6.3 \%) \\
25(4.9 \%)\end{array}$ & $\begin{array}{l}861(61.6 \%) \\
305(20.8 \%) \\
123(8.8 \%) \\
66(4.7 \%) \\
43(3.1 \%) \\
\end{array}$ \\
\hline $\begin{array}{l}\text { Category of Bite : } \\
\text { CAT I } \\
\text { CAT II } \\
\text { CAT III } \\
\end{array}$ & $\begin{array}{l}351(39.6 \%) \\
272(30.7 \%) \\
263(20.7 \%) \\
\end{array}$ & $\begin{array}{l}0(0.0 \%) \\
11(2.1 \%) \\
501(97.9 \%)\end{array}$ & $\begin{array}{l}351(25.1 \%) \\
283(20.2 \%) \\
764(54.7 \%) \\
\end{array}$ \\
\hline $\begin{array}{l}\text { Type of Animal : } \\
\text { Dog } \\
\text { Others }\end{array}$ & $\begin{array}{l}720(83.3 \%) \\
166(18.7 \%)\end{array}$ & $\begin{array}{l}467(91.2 \%) \\
45(8.8 \%)\end{array}$ & $\begin{array}{l}1187 \\
(84.9 \%) \\
211(15.1 \%)\end{array}$ \\
\hline $\begin{array}{l}\text { Vaccine Completed: } \\
\text { Yes } \\
\text { No }\end{array}$ & $\begin{array}{l}726(81.9 \%) \\
160(18.1)\end{array}$ & $\begin{array}{l}443(86.5 \%) \\
69(13.5 \%)\end{array}$ & $\begin{array}{l}1169 \\
(83.6 \%) \\
229(16.4 \%)\end{array}$ \\
\hline
\end{tabular}

Table - 2 : Animal bite related data among the study groups $(\mathrm{n}=1398)$

Table 2 depicts the most common site of animal bite was the lower limb which was about $62 \%$ of the total victims. The next common site was the upper limb, $21 \%$ and $3.1 \%$ victims were found to have multiple bites. Majority of the patients belonged to CAT III (54.7\%). About $85 \%$ bite to be caused by dogs and the other $15 \%$ were caused by others animals such as cat, monkey, rat etc. Vaccine completion was observed in around $84 \%$ of total patients.

\begin{tabular}{|l|l|l|l|}
\hline Bite Related Data & $\begin{array}{l}\text { Male } \\
(\mathbf{n = ~ 8 7 9 )}\end{array}$ & $\begin{array}{l}\text { Female } \\
(\mathbf{n = 5 1 9})\end{array}$ & $\begin{array}{l}\text { Total } \\
(\mathbf{n = 1 3 9 8})\end{array}$ \\
\hline Site of Bite : & $523(59.5 \%)$ & $338(65.1 \%)$ & $861(61.6 \%)$ \\
Lower Limb & $199(22.6 \%)$ & $106(20.4 \%)$ & $305(21.8 \%)$ \\
Upper Limb & $87(9.9 \%)$ & $36(6.9 \%)$ & $123(8.8 \%)$ \\
Head/Face & $43(4.9 \%)$ & $23(4.1 \%)$ & $66(4.7 \%)$ \\
Trunk & $27(3.1 \%)$ & $16(3.1 \%)$ & $43(3.1 \%)$ \\
Multiple Bites & $193(22.0 \%)$ & $158(30.4 \%)$ & $351(25.1 \%)$ \\
\hline Category of Bite : & $164(18.7 \%)$ & $119(22.9 \%)$ & $283(20.2 \%)$ \\
CAT I & $522(59.4 \%)$ & $242(46.6 \%)$ & $764(54.7 \%)$ \\
CAT II & & & \\
CAT III & $774(88.1 \%)$ & $413(79.6 \%)$ & $1187(84.9 \%)$ \\
\hline Type of Animal : & $105(11.1 \%)$ & $106(20.4 \%)$ & $211(15.1 \%)$ \\
Dog & & & \\
Others & $736(83.7 \%)$ & $433(83.4 \%)$ & $1169(83.6 \%)$ \\
\hline Vaccine Completed : & $143(16.3 \%)$ & $86(16.6 \%)$ & $229(16.4 \%)$ \\
Yes & No &
\end{tabular}

Table $-\mathbf{3}$ : Bite related data according to sex $(\mathrm{n}=1398)$ 
Table 3 describes lower limb was most commonly affected in both male and female which was respectively $59.5 \%$ and $65.1 \%$ male were inflicted in $59.4 \%$ while female had suffered in $46.6 \%$ of cases. Male-female ratio was found to be almost equal in case of vaccine completion.

\begin{tabular}{|l|c|c|c|}
\hline Bite Related Data & $\begin{array}{l}<\mathbf{1 5} \text { Years } \\
(\mathbf{n = 7 3 2})\end{array}$ & $\begin{array}{l}\geq \mathbf{1 5} \text { Years } \\
(\mathbf{n = 6 6 6})\end{array}$ & $\begin{array}{l}\text { Total } \\
(\mathbf{n = 1 3 9 8})\end{array}$ \\
\hline Site of Bite : & $413(56.4 \%)$ & $448(67.3 \%)$ & $861(61.6 \%)$ \\
Lower Limb & $159(21.7 \%)$ & $146(21.9 \%)$ & $305(21.8 \%)$ \\
Upper Limb & $86(11.7 \%)$ & $37(5.6 \%)$ & $123(8.8 \%)$ \\
Head/Face & $47(6.4 \%)$ & $19(2.4 \%)$ & $66(4.7 \%)$ \\
Trunk & $27(3.7 \%)$ & $16(2.4 \%)$ & $43(3.1 \%)$ \\
Multiple Bites & $181(24.7 \%)$ & $170(25.5 \%)$ & $351(25.1 \%)$ \\
Category of Bite : & $128(17.5 \%)$ & $155(23.3 \%)$ & $283(20.2 \%)$ \\
CAT I & $423(57.8 \%)$ & $341(51.2 \%)$ & $764(54.7 \%)$ \\
CAT II & $644(88.0 \%)$ & $543(81.5 \%)$ & $1187(84.9 \%)$ \\
CAT III & $88(12.0 \%)$ & $123(18.5 \%)$ & $211(15.1 \%)$ \\
\hline Type of Animal : & $621(84.8 \%)$ & $548(82.3 \%)$ & $1169(83.6 \%)$ \\
Dog & $111(15.2 \%)$ & $118(17.7 \%)$ & $229(16.4 \%)$ \\
Others & &
\end{tabular}

Table - 4: Bite related data according to age group $(n=1398)$

Table 4 illustrates among the sites of bite lower limb was most commonly found to be inflicted in both age groups(56.4\%vs $67.3 \%)$ including CAT III bites were $57.8 \%$ in $<15$ years of age and $51.2 \%$ in $\geq 15$ years age group. Vaccine completion rate was equal between the two age groups, $84.8 \%$ vs $82.3 \%$.

\begin{tabular}{|l|c|c|c|c|c|}
\hline \multicolumn{1}{|c|}{ STUDY GROUP } & N & MEAN & MEDIAN & RANGE & \multirow{2}{*}{ SIGN.* } \\
\cline { 1 - 5 } Group A (ARV) & 886 & 5.82 & 1.00 & $0-222$ & \\
\cline { 1 - 5 } Group B (ARV+RIG) & 512 & 1.73 & 1.00 & $0-90$ & \multirow{2}{*}{$\mathrm{P}=0.000^{\mathrm{HS}}$} \\
\cline { 1 - 5 } Total & 1398 & 4.32 & 1.00 & $0-222$ & \\
\hline
\end{tabular}

Table -5 : Interval between date of bite and vaccination (days) among the study groups $(\mathrm{n}=1398)$

* Independent samples $\mathrm{t}$ - test. HS $=$ Highly Significant $(\mathrm{P}<0.001)$

Table 5 expresses mean time interval between date of bite and vaccination (in days) in group A was about 6 days and in group B it was about 2 days. The mean difference with group A and group B was found to be statistically significant ( $\mathrm{p}<0.001)$, which indicates that the more severely bitten patients (group B) came earlier than the lesser (group A) patients.

\begin{tabular}{|l|c|c|c|}
\hline Location & $\begin{array}{c}\text { Group A } \\
(\text { ARV) } \\
(\mathbf{n = ~ 8 8 6 )}\end{array}$ & $\begin{array}{c}\text { Group B } \\
(\mathbf{A R V + R I G )} \\
(\mathbf{n}=\mathbf{5 1 2})\end{array}$ & $\begin{array}{c}\text { Total } \\
(\mathbf{n}=\mathbf{1 3 9 8})\end{array}$ \\
\hline Chittagong(Rural) : & $\mathbf{5 1 0}(\mathbf{5 7 . 6 \%})$ & $\mathbf{3 2 0}(\mathbf{6 2 . 5 \%})$ & $\mathbf{8 3 0}(\mathbf{5 9 . 4 \%})$ \\
Anowara & 11 & 6 & 17 \\
Banskhali & 6 & 4 & 10 \\
Boalkhali & 14 & 35 & 49 \\
Chandanaish & 3 & 2 & 5 \\
Fatikchhari & 8 & 18 & 26 \\
Hathazari & 9 & 10 & 19 \\
Lohagara & 0 & 1 & 1 \\
Mirsharai & 12 & 12 & 24 \\
Patiya & 12 & 15 & 27 \\
Rangunia & 10 & 15 & 25 \\
Raozan & 7 & 7 & 14 \\
Sandwip & 2 & 0 & 2 \\
Satkania & 2 & 7 & 9 \\
Sitakunda & 414 & 188 & 602 \\
\hline Chittagong(Urban) $:$ & $\mathbf{3 6 8 ( 4 1 . 5 \% )}$ & $\mathbf{1 8 4}(\mathbf{3 5 . 9 \%})$ & $\mathbf{5 5 2}(\mathbf{3 9 . 5 \%})$ \\
\hline Others : & $\mathbf{8 ( 0 . 9 \% )}$ & $\mathbf{8}(\mathbf{1 . 6 \%})$ & $\mathbf{1 6}(\mathbf{1 . 1 \% )}$ \\
\hline
\end{tabular}

Table $-\mathbf{6}$ : Location of the animal bite patients $(\mathrm{n}=1398)$

Table 6 details the total of 59.4\% of animal bite patients came from the rural areas, while $39.5 \%$ were from the urban areas. Most of the rural patients came from the Sitakundu thana.16 patients came from other areas of greater Chittagong Division like Feni, Cox's bazar ,Khagrachori etc. 




Line Graph - 1 : Distribution of animal bite patients according to months (2015)

Line graph.1 shows though animal bites are reported to be more common in September-October months, in our institution we found the highest incidences were in November, than in September- October.

\section{DISCUSSION}

Among the analyzed patients, Category 111 bites were more prevalent at $54.7 \%$. The total of $84 \%$ of the patients who attended for rabies PEP completed the vaccination schedule. Most of the CAT- III patients attended the institute within 2 days of the animal bites. No patients had any adverse effect following vaccination or RIG and none had developed Rabies.

About 52\% were under 15 years of age and about $49 \%$ were at or above 15 years. Though vulnerable age of animal bite is under 15 years, but in our institution age variation was not remarkable.Male were predominantly affected in both study groups (57.4\% vs 72.3$)$. [Table.1]

The most common site of animal bite was in the lower limb which was in around $62 \%$ of the total victims. The next common site was the upper limb, $21 \%$ and the total $43(3.1 \%)$ victims were found to have received multiple bites. Majority of the patients belonged to CAT III (54.7\%). In Bangladesh dog bite is reported as the commonest animal bite. In our Institution we have also found about $85 \%$ bite to be caused by dogs and the other $15 \%$ were caused by others animals such as cat, monkey, rat etc. Vaccine completion was observed in around $84 \%$ of total patients. [Table.2]

From all the victims 27 male patients suffered bites at multiple sites. The incidence of CAT III bite was not found to be much different between the two sexes, male were inflicted in $59.4 \%$ while female had suffered in $46.6 \%$ of cases. Male-female ratio was found to be almost equal in case of vaccine completion. [Table .3]

Among the sites of bite lower limb was most commonly found to be inflicted in both age groups $(56.4 \%$ vs $67.3 \%$ ) including CAT III bites were $57.8 \%$ in $<15$ years of age and $51.2 \%$ in $\geq 15$ years age group. Vaccine completion rate was equal between the two age groups, $84.8 \%$ vs $82.3 \%$. [Table. 4 ]

Mean time interval between date of bite and vaccination (in days) in group A was about 6 days and in group B it was about 2 days. The mean difference with group A and group B was 
found to be statistically significant ( $\mathrm{p}<0.001)$, which indicates that the more severely bitten patients (group B) came earlier than the lesser (group A) patients. [Table 5]

The total of $59.4 \%$ of animal bite patients came from the rural areas, while $39.5 \%$ were from the urban areas. Most of the rural patients came from the Sitakundu thana.16 patients came from other areas of greater Chittagong Division like Feni, Cox's bazar ,Khagrachori etc. [Table-6]

Though animal bites are reported to be more common in September-October months, in our institution we found the highest incidences were in November, than in September- October. [Line graph.1]

\section{CONCLUSION}

A proper understanding of the epidemiology and impact of rabies and animal bite is crucial for planning, implantation and evaluating rabies control program. We could find that WHO or national guidelines were not followed in some of the cases, that is a large number of CAT I bite patients were given ARV; which might be due to the improper patient selection by the physicians during the early part of the vaccination program for their lack of training. This finding implicates the importance of training of the staff and physicians regarding this program.

\section{RECOMMENDATIONS}

From the above findings the following recommendations can be provided:

- The supply of RIG should be increased as there are more category III animal bite patients than category II.

- Moreover proper training of the doctors and staffs regarding rabies post-exposure prophylaxis and record keeping is also an important need.

- We recommend that there should be some changes in the registration book, like inclusion of the hospital registration number, whether Tetanus toxoid was given or not and did the patient require hospital admission or specialty (like plastic surgery) referral that is to be included.

- A proper follow-up schedule needs to be mentioned both in the guidelines and to be included in the register thereof so that the patients can be asked to follow up at regular intervals following the prophylaxis.

- Scaling up of the mass dog vaccination and sterilization in the locality is also a need that is felt, as the program is yet to be started in the local community.

\section{References}

Health Bulletin, 2015.Goverment of the people's Republic of Bangladesh, Ministry of health and family welfare.

WHO. WHO expert consultation on Rabies. First report. WHO technical report series. 2004; 931:1-121.

World Health Organization. Expert consultation on Rabies, Technical report series 931, Geneva, Switzerland, 2005.

Dutta JK. Adverse reactions to purified chick embryo cell rabies vaccine. Vaccine 1994;12:1484 